International Journal of Child, Youth and Family Studies (2012) 4.1: 500-520

\title{
EXPLORING DEVELOPMENTAL ASSETS IN UGANDAN YOUTH
}

\section{Christopher F. Drescher, Eu Gene Chin, Laura R. Johnson, and Julie S. Johnson-Pynn}

\begin{abstract}
Ugandan youth face a number of threats to their healthy development including poverty, high rates of disease, civil conflict, and environmental degradation. Cultivating developmental competencies is critical, not only for youth, but also for the future of Ugandan communities and civil society. In this article, we highlight contextual challenges facing Ugandan youth, report exploratory results on "standard" measures of developmental assets, and discuss the utility of a positive youth development (PYD) framework in Uganda. Despite difficult circumstances, our results indicated high levels of internal and external assets as assessed with the Developmental Assets Profile (DAP). The DAP demonstrated acceptable internal consistencies and was correlated with two other measures of youth assets, self-efficacy, and civic action. Although researchers should proceed with caution when using psychometric measures in new cultural contexts, our results provide preliminary support for the use of the DAP and a PYD framework for advancing adolescent research and programming in Uganda.
\end{abstract}

Keywords: Uganda, positive youth development, developmental assets, self-efficacy, civic action

Acknowledgements: This research project was supported by funds from the National Geographic Society Conservation Trust and the J. W. Fulbright Foundation. We thank collaborators from Makerere University, The Ministry of Environment and Water, the Uganda Wildlife and Education Center, and the Ugandan National Forest Authority.

Christopher F. Drescher, M.A. (the corresponding author) is a clinical psychology doctoral student at the Department of Psychology, University of Mississippi, Peabody Building, Oxford Mississippi, U.S.A., 38677. Phone: (304) 389-4734. E-mail: cfdrescher@gmail.com

Eu Gene Chin, M.A. is a clinical psychology doctoral student at the Department of Psychology, University of Mississippi, Peabody Building, University of Mississippi, Oxford Mississippi, U.S.A., 38677. E-mail: egchin4@gmail.com

Laura R. Johnson, Ph.D. is an Associate Professor of Psychology at the University of Mississippi, Peabody Building, Oxford Mississippi, U.S.A., 38677.

E-mail: ljohnson@olemiss.edu

Julie S. Johnson-Pynn, Ph.D. is an Associate Professor of Psychology at Berry College, 2277 Martha Berry Highway NW, Mount Berry, Georgia, U.S.A., 30149. E-mail: jpynn@berry.edu 
International Journal of Child, Youth and Family Studies (2012) 4.1: 500-520

Rapidly occurring environmental and socio-cultural changes in the landscape of child and adolescent development call our attention to young people's capacity to address major societal problems. Increasingly, youth are becoming engaged in their communities in order to create solutions to society's grand challenges such as poverty, oppression, intercultural conflict, and environmental catastrophes. How to foster youths' sense of purpose, self-efficacy, and commitment to work for the betterment of themselves and of society are key concerns in applied developmental psychology and are relevant the world over (Lerner, 2004; Limber \& Kaufman, 2002; Naudeau, Cunningham, Lundberg, \& McGinnis, 2008).

Enhancing youths' capacity to address challenges in their communities may be especially critical in sub-Saharan African countries where far too many children suffer grave threats to their daily living, such as poverty, civil conflict, high rates of communicable diseases, and loss of family members or social supports (McCandless \& Bangura, 2007; United Nations Development Program [UNDP], 2010). Moreover, developing countries that depend on local resources for subsistence farming are among those (along with island nations) suffering the most immediate effects of environmental degradation and climate change (Chawla, 2002). This is particularly true in equatorial locations like Uganda, where livelihoods depend on predictable growing and rainy seasons. In this article, we highlight contextual challenges facing Ugandan youth, report exploratory results on "standard" measures of youth developmental assets, and discuss the utility of a positive youth development framework for advancing youth research and programming in Uganda.

\section{The Context of Youth in Uganda}

Uganda, a lush equatorial country situated on Lake Victoria, the source of the Nile River, represents one of the most diverse ecosystems in Africa (U.S. Department of State, 2010) and has served as a focal point for anthropologists and environmental researchers for decades. Unfortunately, war and civil conflict, unregulated agricultural practices, illegal mining activities, misuse of natural resources, and a doubling of Uganda's human population in the last 20 years, combine to threaten the sustainability of natural resources (Johnson-Pynn \& Johnson, 2010; Kibanja, Kajumba, \& Johnson, 2012). Poor nutrition, lack of clean water, malaria, and AIDS contribute to high mortality rates in Uganda. Experts have reported that climate change is frustrating poverty eradication programs such as those in the United Nations Millennium Development Goals (Central Intelligence Agency [CIA] World Factbook, 2009; Tenywa, 2007).

In addition to intense environmental pressures, and in large part because of them, sociopolitical unrest threatens the physical and psychological health of individuals and communities. From colonization, through the brutal dictatorships of Amin and Obote, the people of Uganda have suffered numerous socio-political and ethnic conflicts that continue today resulting in an uneasy atmosphere and unsafe situations for youth across the country (Kibanja et al., 2012). The 24-year war with the Lord's Resistance Army (LRA) has resulted in death and displacement on a massive scale, including the conscription of tens of thousands of youth into the LRA. Fighting continues in the west with the Hemu-Lendu conflict on the Congolese border and the Bakiga- 
International Journal of Child, Youth and Family Studies (2012) 4.1: 500-520

Banyoro conflict in Kibale region. Violence also spread to the central regions, including the Buganda Kingdom and the capital in the run-up to the 2011 presidential elections.

As is often the case, children and adolescents face the brunt of the impact associated with these social, economic, and environmental difficulties. High rates of stress due to civil conflicts and daily living conditions result in poor physical and mental health. Epidemiological studies of depression have indicated strikingly high rates (Bolton, Wilks, \& Ndogoni, 2004) compared to global rates and other countries in Africa. Unemployment, homelessness, substance abuse, sex trafficking and prostitution, assault, and child labor are among the concerns facing Ugandan adolescents (Cheney, 2007; Uganda Youth Development Link [UYDEL], 2011). Rural to urban migration and rapid social and cultural changes have also placed new demands to adapt education, employment, family structures, and daily life to keep pace in a rapidly modernizing environment. The needs for infrastructure development, education, health and human services for adolescents remain high.

Faced with such challenges, an exigent need exists for Ugandan communities to build on the skills, talents, and interests of young people, as a means to enhance resilience and empower youth to make a positive difference in their communities. Despite many contextual threats, Ugandan youth may possess strengths and assets, including confidence, family values, school supports, and religious or cultural beliefs that protect them from harm and contribute to their well-being and development. Uganda is a youth-saturated society and with $45 \%$ of the population under age 15, youth have a substantial role to play, for better or worse, in leading Uganda toward social justice and harmony, or toward ongoing conflict. Focusing on adolescent and emerging adult strengths, resources, and contributions through a Positive Youth Development model (PYD) may be a key to constructive research and successful programming.

\section{Positive Developmental Assets Framework}

Positive Youth Development (PYD) is a conceptual approach that emphasizes behavioral, cognitive, emotional, and social competencies in children and adolescents (Catalano, Berglund, Ryan, Lonczak, \& Hawkins, 2004). PYD represents a synergy between normative adolescent development, preventive science, and resilience research traditions (Scales, Benson, Roehlkepartain, Sesma, \& Dulmen, 2006), functioning as a strengths-based framework for promoting mental health and well-being. PYD approaches may be particularly well suited to contexts in which more formal mental health intervention is unavailable or carries stigma (Johnson \& Johnson-Pynn, 2007; Johnson \& Tucker, 2008). Indeed, seeking help from the formal mental health service sector in Uganda is rare, based on the interplay of accessibility, availability, cultural beliefs, and reliance on traditional and social supports for mental health needs (Johnson, Kajumba, Bangirana, \& Kizito, 2009). Despite an unmet need for mental health services in Uganda, many Ugandans would not seek out formal mental health, even if it were available (Johnson et al., 2009).

The PYD emphasis on fostering personal development and strengths would be advantageous in this context. Moreover, PYD aims to create community connections, a sense of 
International Journal of Child, Youth and Family Studies (2012) 4.1: 500-520

purpose, and commitment to civic action for the greater good (Lerner, 2004). These aspects are consistent with socio-centric and collectivist values common among Ugandan cultural beliefs, which increases the acceptability of using a PYD framework for adolescent intervention and research or assessment in Uganda.

Despite the potential benefits of using a PYD approach with youth internationally, there is a paucity of research in this area. As Arnett (2008) explicated, there is an unreasonable research focus on the American population, to the detriment of the other 95\% of the population of this planet. This disparity may be especially present within the African continent given the limited research capacities of African universities (Atuahene, 2011) and its historic neglect by psychologists. Although government and non-government programs exist to promote PYD, there is a dearth of research regarding such programs, and adolescent psychology in general.

\section{Developmental Assets Profile}

The developmental assets framework, which organizes youths' strengths according to relationships, supports, and personal values, is one useful system for research in PYD (Benson, 1997). The framework is based on 40 assets measured by the Developmental Assets Profile (DAP), which groups assets into internal and external domains. The internal assets categories include commitment to learning, positive values, social competencies, and positive identity, while external assets categories include family and community support, empowerment, boundaries and expectations, and constructive use of time. Scores can also be parsed into the context areas of personal, social, family, school, and community. Although norms based on a representative national sample are not yet available, the Search Institute (2004) conducted a field study of U.S. American youth to serve as a preliminary point of comparison for research and fieldwork. This study included a diverse sample of 2,428 boys and girls (Grades 6 through 12) from public middle schools and high schools in Oregon and Minnesota, representing Hispanic, American Indian, Asian, and multiracial youth (Search Institute, 2004).

Studies utilizing the DAP suggest that U.S. youth with more assets were less likely to engage in risky behaviors (e.g., Benson, Roehlkepartain, \& Sesma, 1999) and more likely to endorse indicators of thriving (Benson et al., 1999; Scales, Benson, Leffert, \& Blyth, 2000). Higher scores on the DAP have been reported by girls compared to boys and middle school students compared to high school students (e.g., Leffert et al., 1998). Recently, the DAP has begun to be studied with non-Western youth (Scales, 2011; Wilson, 2010). Scales (2011) reported the data from the use of the DAP in five countries. The psychometric properties of the DAP were generally acceptable within these samples suggesting "that the DAP is usable across a variety of global cultural settings” (Scales, 2011, p. 635). Although these results are promising, they are limited; for example, no African or South American countries were included. Further research is necessary if the DAP is to be reliably used in a wide variety of international youth settings. 
International Journal of Child, Youth and Family Studies (2012) 4.1: 500-520

Despite the limited data available at this time, the DAP is potentially applicable in a number of international applied settings. For example, the DAP may be used by school and mental health personnel as an individual assessment tool or to assess group level assets in settings such as youth programs or schools. This information can be used to highlight strengths and also to identify potential areas for intervention. Furthermore, when the DAP is used in applied research it can help elucidate patterns of youth development across the globe, which is especially important in understudied regions like East Africa.

\section{The Present Study}

Given the challenges facing Ugandan youth and the potential applicability of the Developmental Assets Framework, we wanted to explore the DAP as a viable tool for advancing PYD practice and research in Uganda. The DAP's extensive psychometric development and inclusion of a wide range of developmental assets makes it a potentially useful tool in a variety of programmatic and research contexts. Furthermore, the DAP's ability to highlight different categories and contexts of PYD allow for the tailoring of PYD and other youth programs to meet specific youth needs in a given community.

The study was exploratory and discovery-oriented. We administered the DAP along with measures of self-efficacy and civic attitudes and skills. We hoped the DAP would demonstrate acceptable internal consistencies and demonstrate convergent validity with other PYD measures (i.e., self-efficacy and civic action). Based on previous studies (Leffert et al., 1998), we predicted that the DAP would be related to socio-demographic factors (i.e., socio-economic status, age, gender). We expected some variability between the overall profiles of developmental assets for Ugandan youth in our sample and previous DAP studies.

\section{Method}

\section{Participants}

Participants were Ugandan youth members of school-based Wildlife Clubs of Uganda (WCU; $N=68$; ages 14 to 23, mean age $=18.63$ ) in two forest areas: Kitubulu and Mpanga. WCU's mission is to promote the conservation and scientific study of natural resources and wildlife in Uganda. The wide age range reflects differential entry points and access to school. Participants were unmarried school students, and thus locally, fall into the category of "youth". The majority of participants were male $(n=37 ; 54 \%)$ and most participants spoke three languages: Luganda, English, and their tribal language. Most students’ parents had some education, with the majority of fathers completing some secondary school and mothers completing some primary school (see Table 1).

\section{Procedures}


International Journal of Child, Youth and Family Studies (2012) 4.1: 500-520

This study was a part of a larger project involving youths' participation in communitycentered conservation initiatives in one of two forest areas of Uganda (see Johnson-Pynn \& Johnson, 2005, 2010; Russell, Johnson-Pynn, Johnson, \& Lugumya, 2006). Participants were welcomed to the workshop setting (see Appendix for WCU and workshop details) and invited to participate in the study. Workshops were facilitated by Ugandan youth educators, Ugandan biological scientists, and two U.S. psychologists. Students completed measures before workshop programming began. Measures were completed in English, the official language of Uganda. Program staff members were available for clarification. All procedures were approved by the Institutional Review Board at the University of Mississippi.

\section{Measures}

Developmental Assets Profile. All participants completed the 58-item Developmental Assets Profile or DAP (Search Institute, 2004) in which participants indicate the degree to which statements represent them (e.g., "I deal with frustration in positive ways”) by selecting from four response choices ranging from: "Not At All or Rarely" to "Extremely or Almost Always". Based on a sample of 6th through 12th graders in Minnesota and Oregon, good internal consistencies were obtained for the DAP's total $(\alpha=.97)$ and subscale scores $(\alpha=.81-.95)$. A sub-sample $(n$ $=225$ ) from the same participant pool produced acceptable test-retest reliability values across a span of two weeks: Total Score $(r=.79)$, Internal Assets $(r=.86)$, External Assets $(r=.84)$. Scores on the Positive Identity subscale in the DAP significantly correlated with scores on the Rosenberg's Self-Esteem Scale $(r=.70 ; p<.001)$ and the Harter's Global Self-Worth Scale $(r=$ $.72 ; p<.001$ ) providing evidence for convergent validity of the DAP (Search Institute, 2004). In terms of criterion validity, DAP scores for students in schools with greater resources have been found to be higher than scores for students from less resource-rich schools (Search Institute, 2004).

General Self-Efficacy Scale (GSE). The General Self-Efficacy scale or GSE (Schwarzer \& Jerusalem, 1995) is a 10-item scale developed to assess the respondents' general confidence in coping with a range of stressful circumstances. Respondents endorse their agreement with each item (e.g., "I can always manage to solve difficult problems if I try hard enough") on a 4-point Likert-type scale that ranges from 1 ("Not at all true") to 4 ("Exactly true"). This measure has been translated into 28 languages, based on the German and English versions of the GSE scale. Scholz, Doña, Sud, and Schwarzer (2002) reported internal consistency values (Cronbach $\alpha$ ) from 25 different countries that ranged from .75 to .91. Over a one-year period, Schwarzer and Jerusalem (as cited in Scholz et al., 2002) reported test-retest reliability coefficients of $r=.75$ and $r=.55$ for teachers and students respectively. The GSE has also demonstrated good convergent and divergent validity (Schwarzer, Schmitz, \& Tang, 2000). Additionally, confirmatory factor analyses with international samples support the unidimensionality of the scale (Scholz et al., 2002; Schwarzer \& Born, 1997).

Civic Attitudes and Skills Questionnaire (CASQ). The Civic Attitudes and Skills Questionnaire or CASQ (Moely, Mercer, Ilustre, Miron, \& McFarland, 2002) is a 45-item 
International Journal of Child, Youth and Family Studies (2012) 4.1: 500-520

measure designed to evaluate students' self-perceptions about their own attitudes, skills, and behavioral intentions that may be influenced by participation in service-learning activities. Composed of six scales derived from a principal component analysis (Civic Action, Interpersonal and Problem-Solving Skills, Political Awareness, Leadership Skills, Social Justice Attitudes, and Diversity Attitudes), it requires that respondents indicate their agreement with each item (e.g., "I understand the issues facing this nation”) on a 5-point Likert-type scale that ranges from 1 (“completely disagree”) to 5 (“agree completely”). In terms of reliability, Moely et al. (2002) reported Cronbach's $\alpha$ values that ranged from .69 to .88 for each subscale. Test-retest reliability values over a three month period ranged from .56 to .81 and the CASQ scales also demonstrated good convergent and divergent validity (Moely et al., 2002).

\section{Analysis}

In order to explore the psychometric viability of the DAP with a Ugandan sample, we first calculated descriptive statistics for all DAP scales. We then calculated Cronbach's $\alpha$ for all scores on the DAP and computed bivariate correlations between the DAP and other PYD measures. Next, we conducted independent samples $t$-tests to compare total asset scores across gender and economic status, and a bivariate correlation to assess the relation between age and DAP total score.

\section{Results}

The total asset score for the DAP in our sample was high (median $=49$, mean $=48.51$, standard deviation $=6.52)$. Eighty-seven percent of the sample reported an excellent $(44 \%)$ or good (43\%) level of total assets based on the descriptions suggested by the Search Institute (2004). Throughout the asset categories and context areas, the majority of participants reported abundant or good levels of assets (see Table 2). Asset category scores ranged from 12 to 30 (the maximum possible score) and context area scores range from 8 to 30. Commitment to Learning, composed of items such as "I care about school", was the highest rated asset category $(M=25.9$, $S D=3.57)$. Conversely, Empowerment, which includes items such as "I feel safe and secure at home”, was the lowest rated category $(M=23.1, S D=4.53)$. Within the context areas, Family $(M=25.9, S D=3.38)$ was rated highest and Community $(M=23.0, S D=4.02)$ was rated lowest. The Family context area is comprised of items such as "I have a family that gives me love and support" while the Community features items such as "I am serving others in my community”. Means and standard deviations for all measures within our sample are reported in Table 3.

Preliminary analyses of the DAP yielded very good internal consistency ( $\alpha=.91)$ for the total asset score in our sample, using the guidelines proposed by DeVellis (2003). Internal consistencies for internal and external assets were .88 and .81, respectively. For the asset categories, internal consistencies were .74 (positive identity), .68 (social competencies), .68 (boundaries and expectations), .67 (commitment to learning), .67 (support), .62 (positive values), 
International Journal of Child, Youth and Family Studies (2012) 4.1: 500-520

.59 (empowerment), and .32 (constructive use of time). For the context area scales internal consistencies were .82 (family), .77 (community), .76 (social), .74 (school), and .66 (personal).

\section{Correlations with PYD Constructs}

As expected, the DAP was related to several other PYD scales. The DAP total asset score correlated significantly with scores on the self-efficacy measure, the GSE $(r=.36, p=.003)$ and four of the six CASQ subscales: Civic Action ( $r=.40, p=.001)$, Interpersonal and ProblemSolving Skills ( $r=.38, p=.001)$, Political Awareness $(r=.25, p=.038)$, and Leadership Skills $(r=.31, p=.010)$. At the subscale level, all DAP scores correlated significantly with the GSE or CASQ subscales excluding the Boundaries and Expectations, Support, and Family subscales (see Table 4). To our surprise, DAP scores did not correlate significantly with the Social Justice or Diversity Attitudes scales of the CASQ.

Closer inspection of Table 4 reveals that the internal assets generally have a stronger correlation with the other constructs measured within this study compared to external assets correlation with these constructs. We decided to conduct a post hoc analysis to examine these differential relations. To test the differential strength of the relations between external and internal assets and other variables, we used Chen and Popovich's (2002) test for differences between non-independent correlations for variables that were significantly related to both external and internal assets (GSE, interpersonal problem solving, civic action). Results indicated that the internal assets were more strongly related to interpersonal problem solving scores than external assets $\left(t_{(65)}=1.736, p<.05\right)$. Differences in the strengths of relations were not present for the GSE or civic action scores.

\section{Demographic Factors}

The DAP total score was not significantly related to age $(r=-.04, p>.05)$. Also, the participants who did not have enough money to meet basic needs $(M=49.3)$ did not have a significantly different DAP total score $\left(t_{(65)}=-.776, p>.05\right)$ compared to those who usually or always had enough money to meet basic need $(M=48.0)$. However, females $(M=50.2)$ had a higher mean total asset score than males $\left(M=47.1, t_{(66)}=2.00, p=.049\right)$.

\section{Discussion}

In order for empirical research to continue to develop in this area, psychometrically sound instruments must be adapted or created; one cannot assume measurement equivalence across different cultures and contexts. To that end, this study attempted to explore the viability of using the DAP in a Ugandan youth sample.

Scores were relatively high on the DAP in this Ugandan sample with a mean and median total score of 49 as compared to a median score of 39 from two DAP field studies of U.S. youth (Search Institute, 2004). This result was surprising given the higher level of situational and daily 
International Journal of Child, Youth and Family Studies (2012) 4.1: 500-520

life challenges faced by Ugandan youth as compared to U.S. youth. In the current sample 84\% of youth reported that they were not always able to meet basic needs, yet $87 \%$ reported good or excellent level of assets. This is consistent with survey results reported from the Pew Research Center (2010) in which sub-Saharan Africans (despite their low rankings on human development indicators) reported higher rates of optimism compared to individuals from all regions (United Nations, 2010). The mean total score is also considerably higher than scores from any country reported by Scales (2011). Interestingly, our samples had higher scores than youth in Bangladesh and the Philippines who had recently completed PYD programs (Scales, 2011).

At the level of asset categories, participants displayed a relatively high level of assets. Considering all asset categories and context areas, only a single score was lower for our sample as compared to samples from five non-Western countries and the U.S. field trial of the DAP (Scales, 2011). Specifically, Bangladeshi youth who had completed a PYD program scored higher in the Family context area than our sample (Scales, 2011). Additionally, in five of eight asset categories (commitment to learning, positive values, social competencies, positive identity, and constructive use of time) the present sample reported a higher mean level of assets than a sample of adolescent competitive swimmers in Canada from both large and small communities (Fraser-Thomas, Côté, \& MacDonald, 2010). Only in the asset category of empowerment did swimmers from both small and large communities report a higher mean level of assets than the Ugandan youth participants of this study.

The high scores may reflect selection bias among our participants, who were not only attending school but also were involved in an extracurricular environmental club, potentially indicating access to more supports than typical Ugandan youth. Similar results have been reported with a larger sample of East African youth in conservation clubs who scored higher than comparison samples or reported norms on measures of PYD (Johnson-Pynn \& Johnson, 2010). Although selection bias may be playing some role, these results may also reflect a method bias (e.g., extreme response style) that can be present when measures are transported to a new context (Byrne et al., 2009).

Females reported a higher level of overall assets as compared to males within our sample. Although this is somewhat surprising given the status of women in developing countries like Uganda, it is consistent with reports from U.S. samples that note high levels of assets among girls (e.g., Leffert et al., 1998). It is possible that while girls may have fewer resources and opportunities, their roles and responsibilities may facilitate their personal growth. It is also possible that selection bias is operating to create this gender difference given that these girls were exceptional for Uganda; they are female adolescents who are enrolled in school and participating in an extracurricular activity. Further research is necessary to substantiate this difference and explore its potential implications.

Results from this study indicate very good internal consistencies (using the guidelines proposed by DeVellis, 2003) for the total, internal, and external assets scores of DAP and respectable internal consistency for the context scales of the DAP. Two asset category scales 
International Journal of Child, Youth and Family Studies (2012) 4.1: 500-520

(Constructive Use of Time and Empowerment) yielded low internal consistencies. These category scales also were the least internally consistent of the DAP subscales during the initial field trial of the DAP, and had the lowest alphas among non-white participants (Search Institute, 2004). Furthermore, the majority of non-Western youth samples reported by Scales (2011) demonstrated less than promising reliability (i.e., $\alpha<.60$ ) for these scales. Users should be cautious when interpreting these scales without further psychometric development. Hence, the findings of this study also point toward future research that can improve the psychometric properties of these scales.

The developmental assets correlated moderately with other PYD constructs, although the correlations were much smaller in magnitude than the developmental assets' correlations with positive measures in U.S. samples (Search Institute, 2004). The correlations with other PYD constructs offer preliminary evidence of the convergent validity of the DAP in a Ugandan context, but further investigation is necessary to substantiate this finding.

Generally, internal assets appeared to be stronger predictors of the other PYD constructs measured in this study than the external assets, especially in the case of interpersonal problem solving. A possible explanation for this finding is that the other constructs, measured by the CASQ and GSE, could also be classified as “internal” (i.e., an individual quality). It is possible that if more contextual variables had been measured (e.g., community efficacy), the external assets would have been more strongly related to these constructs. Further studies including both personal and contextual variables can further clarify the discriminant validity of these DAP subscales.

Notwithstanding identified areas needing more research, results from this study support the notion that PYD is a promising framework when used with Ugandan youth populations. Youth in developing countries often receive programmatic attention only after they engage in risky behavior and/or experience negative outcomes (Naudeau et al., 2008). Yet, as Naudeau and colleagues note, it is more beneficial for youth and less costly for society to focus on PYD and prevention rather than post hoc interventions. Indeed, Patel, Flisher, Nikapota, and Malhotra (2008) have noted that proactive community-based mental health promotion programs focusing on reducing risk factors and strengthening protective factors may be the best way to meet the mental health needs of youth from low- and middle-income countries. The potential benefits of such programming for youth and their communities are exemplified by a statement from a youth member of WCU: "I think I will solve the problems by educating my community members what I have learned and put into practice.” Further demonstrating the empowerment and efficacy experienced by PYD participants, a second WCU member declared: "I should act as an example to my community. I will be able to mobilize people to work together and conserve the environment for a better future.”

Additionally, an assessment of developmental assets may be useful for social workers, teachers, health care workers, and others, such as non-government organizations (NGOs) working with youth populations in Uganda. While a PYD framework offers many benefits, 
International Journal of Child, Youth and Family Studies (2012) 4.1: 500-520

measurement of clinical variables and risk factors (e.g., depression, PTSD, substance use, exposure to violence, civil unrest) should be included to give a full snapshot of youth development internationally. This is especially important in countries like Uganda where the landscape of youth development is characterized by such multiple threats as poverty, illness, and civil conflict (e.g., Bolton et al., 2004). Future research should continue within the PYD paradigm and examine the DAP and other measures associated with behavioral outcomes relevant to Ugandan and other international youth.

Although the results of this study show promise concerning the use of the DAP and PYD within a Ugandan population, they must be interpreted with caution for a few reasons. First, our sample included some participants who were older (ages ranged from 14 to 23 years old) than the recommended age range for the DAP (11 to 18 years old). However, we found no relation between the DAP and age. Additionally, other international samples (e.g., the Lebanese sample within Scales, 2011) have successfully included participants in their early 20s.

Second, there is some concern about the conceptual equivalence across cultures of some DAP items. Even though normed assessments like the DAP give us the convenience of comparing developmental assets across international populations, the singular use of it constitutes a limitation to our study since pre-designated items and response options developed for use with one population (e.g., American youths) may not function the same way when transported to another population of a different culture (e.g., Ugandan youths). For example, initial pilot data with a Swahili version of the DAP indicated that concepts included in the DAP, such as "family", "neighborhood", and "caring" have a differential meaning in an East African context (Cupit, 2011). Concerns about method bias, differential item functioning, expectancy bias, response sets, and cultural distrust also remain. Further psychometric studies of the DAP are needed.

Other limitations are the small sample size and the lack of qualitative data. Larger scale quantitative studies are needed to further assess the DAP, including factor analyses. At this stage, qualitative studies are also important, as social, cultural, and ecological factors will shape a society's attitudes about youth. Open-ended interviews with youth, teachers, parents, village elders, and professionals could reveal unique and varying perspectives on developmental assets (Popay, Rogers, \& Williams, 1998). More studies should gear toward adapting measures for maximum validity within particular contexts, especially in areas of the world such as Uganda, which are ignored by the majority of psychological research. Despite these limitations, we believe that this study provides a starting point for further investigations of the DAP as a framework for assessing youth development in a way that is relevant in Uganda. Future studies can build on this work by evaluating PYD in diverse Ugandan youth and other international youth samples. Ultimately, further research is necessary to highlight the important role that a PYD approach can play internationally.

\section{Conclusion}


International Journal of Child, Youth and Family Studies (2012) 4.1: 500-520

Active participation in communities may be especially critical for youth living in poverty or whose daily lives are threatened by environmental degradation or civil conflict. In Uganda, a history of ethno-political conflicts combine with current conflicts, economic pressures, and intransigent leaders to undermine a nation and a people in nearly all domains of life. While there is certainly a need to address problems, this strengths-based framework appears to be a viable approach to advancing research and programming and, ultimately, enhancing youth well-being in Uganda. Future research should continue to explore the use of the DAP along with measures of youth risks and behavioral outcomes. An international research agenda to enhance youth wellbeing should include an examination of youth-positive assets through multiple methods of inquiry within and across cultural groups.

\section{References}

Arnett, J. J. (2008). The neglected 95\%: Why American psychology needs to become less American. American Psychologist, 63(7), 602-614.

Atuahene, F. (2011). Re-thinking the missing mission of higher education: An anatomy of the research challenge of African universities. Journal of Asian \& African Studies, 46(4), 321-341.

Benson, P. L. (1997). All kids are our kids: What communities must do to raise caring and responsible children and adolescents. San Francisco: Jossey-Bass.

Benson, P. L., Roehlkepartain, E. C., \& Sesma, Jr., A. (1999). Tapping the power of community: Building assets to strengthen substance abuse prevention. Search Institute's Insight \& Evidence, 2, 11.

Bolton, P. Wilks, L., \& Ndogoni, D. (2004). Assessment of depression prevalence in rural Uganda based on symptom and functional criteria. Social Psychology and Psychiatric Epidemiology, 39, 442-449.

Byrne, B. M., Oakland, T., Leong, F. T. L., van de Vijver, F. J. R., Hambleton, R. K., Cheung, F. M., \& Bartram, D. (2009). A critical analysis of cross-cultural research and testing practices: Implications for improved education and training in psychology. Training and Education in Professional Psychology, 3(2), 94-105. 
International Journal of Child, Youth and Family Studies (2012) 4.1: 500-520

Catalano, R. F., Berglund, M. L., Ryan, J. A. M., Lonczak, H. S., \& Hawkins, J. D. (2004). Positive youth development in the United States: Research findings on evaluations of positive youth development programs. The ANNALS of the American Academy of Political and Social Science, 591(1), 98-124.

Central Intelligence Agency (CIA) World Factbook. (2004). Retrieved November 26, 2010 from https://www.cia.gov/library/publications/the-world-factbook/geos/ug.html

Chawla, L. (2002). The effects of political and economic transformations on children: The environment. In N. H. Kaufman \& I. Rizzini (Eds.), Globalization and children: Exploring potentials for enhancing opportunities in the lives of children and youth (pp. 91-98). New York: Kluwer Academic/Plenum Publishers.

Chen, P. Y., \& Popovich, P. M. (2002). Correlation: Parametric and nonparametric measures. Newbury Park, CA: Sage Publications.

Cheney, K. E. (2007). Pillars of the nation: Child citizens and Ugandan national development. Chicago: University of Chicago.

Cupit, A. H. (2011). Positive youth development in Tanzania: Creating a Swahili version of the Developmental Assets Profile. Unpublished honors thesis, University of Mississippi, Oxford.

DeVellis, R. F. (2003). Scale development: Theory and applications. Thousand Oaks, CA: Sage.

Fraser-Thomas, J., Côté, J., \& MacDonald, D. J. (2010). Community size in youth sport settings: Examining developmental assets and sport withdrawal. PHENex Journal, 2(2), 1-9.

Johnson, L. R., \& Johnson-Pynn, J. S. (2007). Cultivating compassion and youth action around the globe: A preliminary report on Jane Goodall's Roots \& Shoots program. Journal of Youth Development, 2(2). Retrieved from www.nae4ha.org.

Johnson, L.R., Kajumba, M. M., Bangirana, P., \& Kizito, S. (2009). Contrasting concepts of depression in Uganda: Implications for service delivery in a multicultural context. American Journal of Orthospsychiatry, 79(2), 275-289.

Johnson, L. R., \& Tucker, C. (2008). Cultural issues. In M. Hersen \& A. M. Gross (Eds.), Handbook of clinical psychology: Vol. 2. Children and adolescents (pp. 789-832). Hoboken, NJ: John Wiley \& Sons.

Johnson-Pynn, J. S., \& Johnson, L. R. (2005). Successes and challenges in East African conservation education. Journal of Environmental Education, 36, 25-39. 
International Journal of Child, Youth and Family Studies (2012) 4.1: 500-520

Johnson-Pynn, J. S., \& Johnson, L. R. (2010). Exploring environmental education for East African youth: Do program contexts matter? Children, Youth and Environments, 20, 123151.

Kibanja, G., Kajumba, M. M., \& Johnson, L. R. (2012) Ethno-cultural conflict in Uganda: Politics based on ethnic divisions inflame tensions across the country. In D. Landis \& R. Albert (Eds.), Handbook of ethnocultural conflict (pp. 403-435). New York: Springer.

Leffert, N., Benson, P. L., Scales, P. C., Sharma, A. R., Drake, D. R., \& Blyth, D. A. (1998). Developmental assets: Measurement and prediction of risk behaviors among adolescents. Applied Developmental Science, 2(4), 209-230.

Lerner, R. M. (2004). Liberty: Thriving and civic engagement among American youth. Thousand Oaks, CA: Sage Publications.

Limber, S. P., \& Kaufman, N. H. (2002). Civic participation in children and youth. In N. H. Kaufman \& I. Rizzini (Eds.), Globalization and children: Exploring potentials for enhancing opportunities in the lives of children and youth (pp. 81-90). New York: Kluwer Academic/Plenum Publishers.

Moely, B. E., Mercer, S. H., Ilustre, V., Miron, D., \& McFarland, M. (2002). Psychometric properties and correlates of the Civic Attitudes and Skills Questionnaire (CASQ): A measure of students' attitudes related to service-learning. Michigan Journal of Community Service-Learning, 8, 15-26.

McCandless, E., \& Bangura, A. K. (2007). African experiences and challenges. In M. King \& E. Sall (Eds.), Peace research for Africa: Critical essays on methodology (pp. 55-70). Addis Ababa: University for Peace.

Naudeau, S., Cunningham, W., Lundberg, M. K. A., \& McGinnis, L. (2008). Programs and policies that promote positive youth development and prevent risky behaviors: An international perspective. In N. G. Guerra \& C. P. Bradshaw (Eds.), Core competencies to prevent problem behaviors and promote positive youth development [Special Issue]. New Directions for Child and Adolescent Development, 122, 75-87.

Patel, V., Flisher, A. J., Nikapota, A., \& Malhotra, S. (2008). Promoting child and adolescent mental health in low and middle income countries. Journal of Child Psychology and Psychiatry, 49(3), 313-334.

Pew Research Center. (2010). Tolerance and tension: Islam and Christianity in sub-Saharan Africa. Washington, DC: Pew Forum on Religion and Public Life. Retrieved from 
International Journal of Child, Youth and Family Studies (2012) 4.1: 500-520

http://www.pewforum.org/executive-summary-islam-and-christianity-in-sub-saharanafrica.aspx.

Popay, J., Rogers, A., \& Williams, G. (1998). Rationale and standards for the systematic review of qualitative literature in health service research. Qualitative Health Research, 8(3), 341-351.

Russell, J. L., Johnson-Pynn, J. S., Johnson, L. R., \& Lugumya, D. (2006). Wildlife clubs of Uganda: Collective youth action to protect Uganda's primates. International Journal of Primatology, 27, 310-311.

Scales, P. C. (2011). Youth developmental assets in global perspective: Results from international adaptations of the Developments Assets Profile. Child Indicators Research, 4, 619-645.

Scales, P. C., Benson, P. L., Leffert, N., \& Blyth, D. A. (2000). Contribution of developmental assets to the prediction of thriving among adolescents. Applied Developmental Science, 4(4), 27-46.

Scales, P. C., Benson, P. L., Roehlkepartain, E. C., Sesma, Jr., A., \& Dulmen, M. V. (2006). The role of developmental assets in predicting academic achievement: A longitudinal study. Journal of Adolescence, 29(5), 691-708.

Scholz, U., Doña, B. G., Sud, S., \& Schwarzer, R. (2002). Is general self-efficacy a universal construct? Psychometric findings from 25 countries. European Journal of Psychological Assessment, 18(3), 242-251.

Schwarzer, R., \& Born, A. (1997). Optimistic self-beliefs: Assessment of general perceived selfefficacy in thirteen cultures. World Psychology, 3(1/2), 177-190.

Schwarzer, R., \& Jerusalem, M. (1995). Generalized self-efficacy scale. In J. Weinman, S. Wright, \& M. Johnston (Eds.), Measures in health psychology: A user's portfolio. Causal and control beliefs (pp. 35-37). Windsor, UK: NFER-Nelson.

Schwarzer, R., Schmitz, G. S., \& Tang, C. (2000). Teacher burnout in Hong Kong and Germany: A cross-cultural validation of the Maslach Burnout Inventory. Anxiety, Stress, \& Coping, 13(3), 309-326.

Search Institute. (2004). Developmental assets profile preliminary user manual. Minneapolis, MN: Author.

Tenywa, G. (2007, April). Climate change hits Uganda. New Vision, 22. Retrieved from http://www.newvision.co.ug/D/8/12/558362. 
International Journal of Child, Youth and Family Studies (2012) 4.1: 500-520

Uganda Youth Development Link (UYDEL). (2011). Study on commercial sexual exploitation of children in Uganda. Retrieved from http://www.uydel.org/downloads/Police\%20meeting\%20report\%20\%20CSEC\%20final\%201-20111102-163707.pdf

United Nations. (2010). Human development report. Retrieved March 10, 2011 from http://hdr.undp.org/en/reports/global/hdr2010/

United Nations Development Program (UNDP). (2010). Assessing Africa's progress toward the millennium developmental goals. MDG Progress Report 2010. New York: Author.

U.S. Department of State (2010, June). Background note: Uganda. Retrieved from http://www.state.gov/r/pa/ei/bgn/2963.htm.

Wilson, A. (2010). Adaptation of surveys across cultures: The DAP in Japan. Retrieved November 26, 2010 from http://www.l.yamaguchipu.ac.jp/archives/2010/part1/01.Intercultural\%20Studies/Inter_08_WILSON.pdf 
International Journal of Child, Youth and Family Studies (2012) 4.1: 500-520

Table 1: Socio-economic Status of Participants

\begin{tabular}{|c|c|c|}
\hline Socio-economic indicator & Response & Percentage of sample \\
\hline \multirow{5}{*}{ Ability to Meet Basic Needs } & Do not meet & 32 \\
\hline & Usually meet & 52 \\
\hline & Always meet & 15 \\
\hline & More than enough & 0 \\
\hline & No Response & 2 \\
\hline \multirow{8}{*}{ Father’s Educational Level } & None & 4 \\
\hline & Primary School & 16 \\
\hline & Secondary School & 32 \\
\hline & Some college or technical & 19 \\
\hline & College graduate & 7 \\
\hline & Graduate degree & 15 \\
\hline & Do not know & 4 \\
\hline & No Response & 2 \\
\hline \multirow{8}{*}{ Mother’s Educational Level } & None & 9 \\
\hline & Primary school & 28 \\
\hline & Secondary school & 34 \\
\hline & Some college or technical & 10 \\
\hline & College graduate & 6 \\
\hline & Graduate degree & 9 \\
\hline & Do not know & 3 \\
\hline & No Response & 2 \\
\hline
\end{tabular}


International Journal of Child, Youth and Family Studies (2012) 4.1: 500-520

Table 2: Asset Levels for Asset Categories and Context Areas

\begin{tabular}{|c|c|c|c|c|}
\hline \multirow{2}{*}{ DAP Scale } & \multicolumn{4}{|c|}{ Level of Assets (\%) } \\
\hline & Excellent/Abundant & Good & Fair & Low \\
\hline \multicolumn{5}{|l|}{ Asset Categories } \\
\hline Positive Values & 41 & 46 & 13 & 0 \\
\hline Social Competencies & 41 & 40 & 18 & 2 \\
\hline Positive Identity & 40 & 28 & 28 & 4 \\
\hline Empowerment & 25 & 46 & 25 & 4 \\
\hline Boundaries \& Expectations & 56 & 28 & 16 & 0 \\
\hline Constructive Use of Time & 43 & 34 & 21 & 3 \\
\hline Support & 43 & 30 & 24 & 4 \\
\hline Commitment to Learning & 68 & 22 & 9 & 2 \\
\hline \multicolumn{5}{|l|}{ Context Areas } \\
\hline Personal & 35 & 49 & 16 & 0 \\
\hline Social & 32 & 49 & 18 & 2 \\
\hline Family & 59 & 24 & 15 & 3 \\
\hline School & 60 & 31 & 9 & 0 \\
\hline Community & 27 & 46 & 27 & 2 \\
\hline
\end{tabular}


International Journal of Child, Youth and Family Studies (2012) 4.1: 500-520

Table 3: Means and Standard Deviations for PYD Measures

\begin{tabular}{|c|c|c|}
\hline \multirow[t]{2}{*}{ Measure } & Subscale & $\begin{array}{l}\text { Total } \\
(N=68)\end{array}$ \\
\hline & & Mean $(S D)$ \\
\hline \multirow{2}{*}{ DAP } & External Asset & $24.00(3.59)$ \\
\hline & Internal Asset & $24.51(3.40)$ \\
\hline \multirow{8}{*}{$\begin{array}{c}\text { DAP } \\
\text { Asset } \\
\text { Categories }\end{array}$} & Commitment to Learning & $25.91(3.57)$ \\
\hline & Positive Values & $24.39(3.28)$ \\
\hline & Social Competencies & $24.18(4.20)$ \\
\hline & Positive Identity & $23.54(4.88)$ \\
\hline & Empowerment & $23.06(4.53)$ \\
\hline & Boundaries \& Expectations & $24.94(3.83)$ \\
\hline & Constructive Use of Time & $24.47(4.70)$ \\
\hline & Support & $23.53(4.53)$ \\
\hline \multirow{5}{*}{$\begin{array}{c}\text { DAP } \\
\text { Context } \\
\text { Areas }\end{array}$} & Personal & $24.27(3.56)$ \\
\hline & Social & $23.81(3.97)$ \\
\hline & Family & $25.08(4.55)$ \\
\hline & School & $25.85(3.28)$ \\
\hline & Community & $22.97(4.02)$ \\
\hline \multirow{6}{*}{ CASQ } & Civic Action & $4.52(0.40)$ \\
\hline & Interpersonal Problem Solving & $4.07(0.54)$ \\
\hline & Political Awareness & $3.51(0.87)$ \\
\hline & Leadership Skills & $3.67(0.66)$ \\
\hline & Social Justice & $3.68(0.51)$ \\
\hline & Diversity Attitudes & $3.72(0.79)$ \\
\hline
\end{tabular}

Note. $*$ = No subscales; DAP = Developmental Assets Profile; CASQ = Civic Attitudes and Skills Questionnaire; GSE = General Self-Efficacy Scale. 
International Journal of Child, Youth and Family Studies (2012) 4.1: 500-520

Table 4: Correlations Between DAP Scores and PYD Constructs

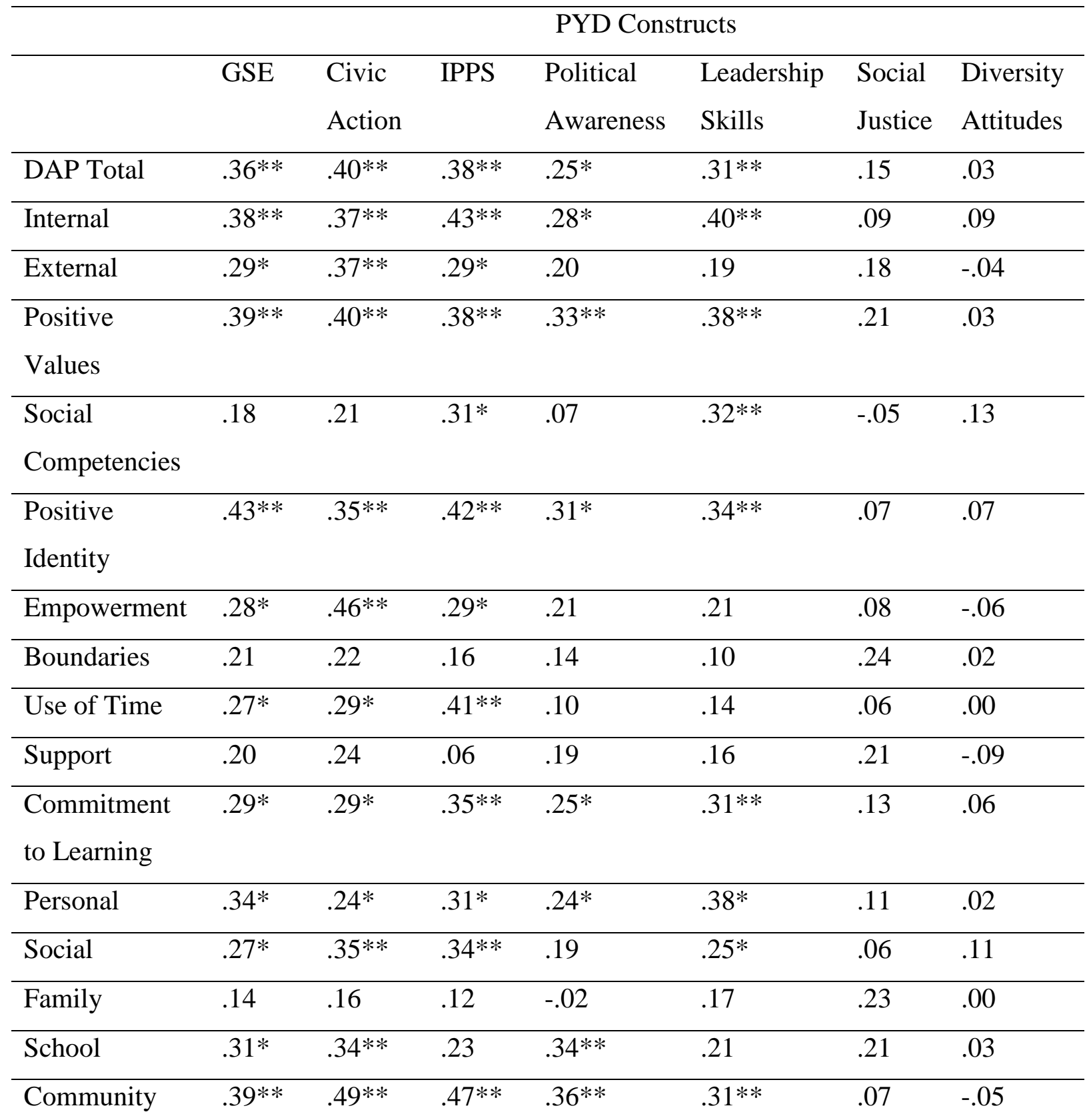

Note: GSE = General Self-Efficacy; IPPS = Interpersonal Problem Solving; ${ }^{*} p<0.05 ; * * p<$ .01 . 
International Journal of Child, Youth and Family Studies (2012) 4.1: 500-520

\section{Appendix}

Description of Youth Programs

\begin{tabular}{|c|c|c|}
\hline Program Description & Pedagogical Approaches & Content/ Topics \\
\hline \multicolumn{3}{|l|}{$\underline{\text { Wildlife Clubs of Uganda }}$} \\
\hline $\begin{array}{l}\text { A non-government } \\
\text { organization, begun in 1975, } \\
\text { designed to instill pride in } \\
\text { Uganda's natural heritage and } \\
\text { to promote conservation and } \\
\text { sustainable development; } \\
\text { youth participate in school- } \\
\text { based clubs. }\end{array}$ & $\begin{array}{l}\text { Hands-on learning via } \\
\text { meaningful community projects; } \\
\text { youth involvement in } \\
\text { community education about the } \\
\text { environment; weekly meetings } \\
\text { facilitate social bonding and } \\
\text { connection. }\end{array}$ & $\begin{array}{l}\text { Focus on community } \\
\text { concerns such as agro- } \\
\text { forestry (tree nurseries), } \\
\text { income generation projects } \\
\text { (bee keeping and eco-- } \\
\text { tourism), anti-poaching, } \\
\text { sanitation, and community } \\
\text { health issues (e.g., malaria). }\end{array}$ \\
\hline \multicolumn{3}{|l|}{$\begin{array}{l}\text { National Geographic } \\
\text { Conservation Trust } \\
\text { Workshops }\end{array}$} \\
\hline $\begin{array}{l}\text { Two- and three-day } \\
\text { residential workshops held at } \\
\text { two Ugandan national forest } \\
\text { preserves; attended by WCU } \\
\text { members from different clubs; } \\
\text { designed to supplement } \\
\text { regular WCU programs. }\end{array}$ & $\begin{array}{l}\text { Youth mentoring by university } \\
\text { scientists; hands-on field } \\
\text { research to assess biodiversity } \\
\text { and health of forests; nature } \\
\text { immersion; bringing diverse } \\
\text { groups (and tribes) together; } \\
\text { film showing and discussion of } \\
\text { An Inconvenient Truth. }\end{array}$ & $\begin{array}{l}\text { Focus on global issues such } \\
\text { as climate change (global } \\
\text { warming), biodiversity and } \\
\text { cultural diversity, inter- } \\
\text { species dependence, social } \\
\text { and political context, and } \\
\text { scientific basis for research } \\
\text { and action. }\end{array}$ \\
\hline
\end{tabular}

